\title{
The role of Ets family transcription factor PU.1 in hematopoietic cell differentiation, proliferation and apoptosis
}

Tsuneyuki Oikawa, ${ }^{\star, 1}$, Toshiyuki Yamada ${ }^{1}$, Fumiko Kihara-Negishi ${ }^{1}$, Hitomi Yamamoto', Nobuo Kondoh ${ }^{1,2}$, Yoshiaki Hitomi ${ }^{1,3}$ and Yoshiyuki Hashimoto ${ }^{1}$

${ }^{1}$ Department of Cell Genetics, Sasaki Institute, 2-2, Kanda-Surugadai, Chiyoda-ku, Tokyo 101-0062, Japan

2 Department of Biochemistry II, National Defense Medical College, 3-2, Namiki, Tokorozawa, Saitama 359-0042, Japan

3 Investigative Treatment Division, National Cancer Center, Research Institute, East, 6-5-1, Kashiwanoha, Kashiwa 277-0882, Chiba, Japan

* corresponding author: T. Oikawa

tel: +81-3-3294-3286; fax: +81-3-3294-3290;

e-mail: toikawa@goldfish.sasaki.or.jp

Received 26.11.98; Revised 7.4.99; Accepted 28.4.99

Edited by R Knight

\begin{abstract}
The PU.1 gene encodes an Ets family transcription factor which controls expression of many B cell- and macrophagespecific genes. Expression of the gene is critical for development of lymphoid and myeloid cell lineages, since PU.1-deficient mice exhibit defects in the development of these cell lineages. The PU.1 gene is identical to the Spi-1 gene isolated from common proviral integration sites in Friend virus-induced murine erythroleukemia (MEL), and deregulated expression of the gene is believed to be an essential step of the disease. We recently demonstrated that overexpression of PU. 1 inhibits erythroid differentiation of MEL cells induced with the differentiating agent DMSO. We also noticed unexpectedly that overexpression of PU.1 together with DMSO induces marked growth arrest and apoptosis in MEL cells, supporting the notion that some oncogenes induce growth inhibition and apoptosis rather than cell proliferation and transformation under specific circumstances as shown with the c-myc gene. In this review, the role of PU.1 in hematopoietic cell differentiation, proliferation and apoptosis is described and the possible molecular mechanisms of PU.1induced effects in MEL cells are discussed.
\end{abstract}

Keywords: PU.1; Spi-1; transcription factor; erythroleukemia; differentiation; proliferation; cell cycle; apoptosis; c-Myc; GATA-1; CBP; cross-talk

Abbreviations: CBP: CREB binding protein; DMSO: dimethylsulfoxide; EMSA: Electrophoretic mobility shift assay; ES cells: embryonic stem cells; GM-CSFR: granulocyte macrophage colony stimulating factor receptor; MEL: murine erythroleukemia; NHR: nuclear hormone receptor; P/CAF: p300/CBP associated factor;
Spi-1: spleen focus forming virus proviral integration-1; TPA: 12-0tetradecanoylphorbol-13-acetate

\section{Introduction}

Hematopoietic cell differentiation is thought to be achieved through promoting proliferation and survival of particular progenitors by hematopoietic growth factors and through differentiation by stochastic and/or hierarchical programmed cascades of the expression of several tissue-specific transcription factors. ${ }^{1,2}$ During these differentiation processes, however, cells with accidental inappropriate expression of the genes that control cell proliferation and/or differentiation might be eliminated by apoptosis, otherwise the cells could be harmful to the host in some cases. This hypothesis is supported by the experimental facts that ectopic or inappropriate overexpression of such transcription factors often triggers off development of malignant tumors ${ }^{3,4}$ and that most of them are also implicated in the process of apoptotic cell death. ${ }^{5}$ Therefore, the molecular events of cell differentiation, proliferation and apoptosis are tightly linked and the pathways of these processes seem to sometimes, if not always, be overlapping to some degree. A typical example has been documented in the c-myconcogene. In various types of normal cells, c-Myc activates transcription by binding to $5^{\prime}$-CACGTG$3^{\prime}$ sequences as a heterodimer with its partner, Max, and acts as a key regulator of cell proliferation. ${ }^{6}$ Deregulated expression of the c-myc gene is implicated in neoplastic transformation of several hematopoietic progenitor cells by promoting cell proliferation and blocking cell differentiation. ${ }^{7}$ Although ectopic expression of c-Myc is sufficient to induce cell cycle entry, overexpression of the c-myc gene induces apoptosis under serum-starved conditions. ${ }^{8}$

In the course of the studies on the role of oncogenes in cell growth and differentiation in hematopoietic cells, we found that overexpression of the PU.1 gene, a member of the ets oncogene family, induces growth inhibition and apoptosis in murine erythroleukemia (MEL) cells under particular circumstances. In this review, we describe the functional role of PU.1 in normal hematopoiesis, and discuss involvement of PU.1 in erythroid differentiation, cell proliferation and apoptosis in murine erythroleukemia (MEL) cells focusing primarily on the data of our recent work. ${ }^{9-13}$

\section{The role of PU.1 in normal hematopoietic cell differentiation}

The PU.1 gene was cloned as a gene that encodes for a protein binding to the promoter of the major histocompatibility complex (MHC) class II I-A $\beta$ gene. ${ }^{14}$ PU. 1 is expressed predominantly in $B$ cells, macrophages and neutrophils but not in T, erythroid nor non-hematopoietic cells. ${ }^{14,15}$ It is a 
member of Ets family transcription factors binding to the $5^{\prime}$ GGAA-3' core purine-rich sequences as a monomer via a highly conserved 85-residue DNA binding domain termed the Ets domain. ${ }^{16,17}$ The molecular size of PU.1 is $4.2 \mathrm{kDa}$ consisting of 272 amino acids (a.a.). The activation domain of PU.1 is located at the N-terminus (a.a. $7-100$ ) followed by a potentially protease-sensitive PEST domain (a.a. 118-160) with a phosphorylation site (Ser 148) and the Ets DNA binding domain (a.a. 168-255) forming an winged helix - turn-helix (wHTH) motif at the C-terminus. ${ }^{18}$ PU.1-deficient $\left(P U .1^{-1-}\right)$ mice exhibit defects in the development of $B$ cells, macrophages and neutrophils, although the generation of erythroid and megakaryocytic cells is intact. ${ }^{19,20} \mathrm{PU}^{-1^{-1-}}$ hematopoietic progenitors fail to express the IL-7 receptor whose signaling is probably required for Pax -5 expression. Thus, the block of $\mathrm{B}$ cell development caused by the PU.1 mutation may be due to the combined defects in IL-7 signaling as well as the failure to induce expression of Pax-5. ${ }^{21}$ $P U .1^{-1-}$ embryonic stem (ES) cells also fail to differentiate into macrophages in vitro. ${ }^{22}$ This failure is complemented by a PU.1 transgene, providing evidence that PU.1 promotes macrophage differentiation from pluripotent ES cells. ${ }^{23}$ PU.1 functions in an exclusively cell-autonomous manner to regulate development of lymphoid and myeloid cells. ${ }^{24}$ Furthermore, the knockout mice also show a hallmark of osteopetrosis, a sclerotic bone disease, with the absence of myeloid-derived osteoclasts as well as macrophages. ${ }^{25}$ Thus, PU.1 appears to be a master regulator, critical for development of a common progenitor for the lymphoidmyeloid cell lineages in the hematopoietic system. It binds to the corresponding sequences in the promoters and enhancers of many B cell- and myeloid-specific genes. The major target genes for PU.1. are listed in Table 1.

In pre-B and $B$ cells, PU.1 regulates the immunoglobulin genes. ${ }^{26}$ A minimal domain of the intronic enhancer of the immunoglobulin $\mu$ heavy-chain $(\operatorname{lgH})$ gene is composed of the $\mu \mathrm{A}, \mu \mathrm{E} 3$ and $\mu \mathrm{B}$ that bind Ets-1, TFE3/AML1 and PU.1, respectively. ${ }^{27}$ In the $\lg \kappa 3^{\prime}$ enhancer, PU.1 apparently can activate transcription by playing an architectural role in interaction with other transcription factors such as c-Fos, cJun and ATF-1. ${ }^{28}$ The PU.1-binding site in the enhancer is also responsible for the negative regulation of tissue ( $T / B$ cell)- and the stage (pro-B/pre-B cell)-specific $V_{\kappa}-J_{\kappa}$ joining. ${ }^{29}$ To activate the $\lg \kappa$ and $\lambda$ enhancer elements, PU.1 has to form a ternary complex with a lymphoidrestricted interferon regulatory factor, IRF-4/NF-EM5/ Pip (PU.1 interaction partner) which contacts DNA on nucleotides immediately adjacent to the PU.1 binding site. ${ }^{30}$ The formation of the PU.1-Pip-DNA complex requires the phosphorylation of Ser 148 in the PEST domain of PU. 1 by Caseine Kinase II. ${ }^{31}$ Interaction of PU.1 with Pip has also been reported in B-lineage-specific expression of the CD20 promoter in co-operation with members of the basic helixloop-helix zipper (bHLHZ) family of transcription factors. ${ }^{32}$

In myeloid cells, PU.1 upregulates various myeloidspecific genes such as the M-CSF receptor (c-fms), GCSF receptor, GM-CSF receptor, Fc $\gamma \mathrm{R}, \mathrm{CD} 11 \mathrm{~b}, \mathrm{CD} 18$, myeloperoxidase (MPO) and c-fes genes. ${ }^{2,33}$ Thus, failure in the development of myeloid lineages during fetal liver hematopoiesis in PU.1-deficient mice ${ }^{19,20}$ could be partly
Table 1 Major target genes for PU.1

\begin{tabular}{|c|c|}
\hline $\begin{array}{l}\text { Target gene } \\
\text { (Enhancer/promoter) }\end{array}$ & References \\
\hline \multicolumn{2}{|l|}{ Lymphocyte } \\
\hline Immunoglobulin heavy-chain $(\mathrm{IgH})$ & 125 \\
\hline Immunoglobulin $\kappa$-chain $(\lg \kappa)$ & 126 \\
\hline Immunoglobulin $\lambda$-chain $(\lg \lambda)$ & 30 \\
\hline Immunoglobulin J-chain & 127 \\
\hline B29 $(\lg \beta)$ & 128 \\
\hline$m b-1$ & 129 \\
\hline CD20 & 32 \\
\hline CD72 & 130 \\
\hline Bruton's tyrosine kinase (Btk) & 131 \\
\hline MHC class II I-A $\beta$ & 132 \\
\hline IL5 receptor $\alpha$ & 133 \\
\hline PU.1 & 41 \\
\hline \multicolumn{2}{|l|}{ Myelomonocyte/Granulocyte } \\
\hline M-CSF (CSF-1) receptor (c-fms) & 134 \\
\hline G-CSF receptor & 135 \\
\hline GM-CSF receptor & 136 \\
\hline Scavenger receptors & 137 \\
\hline CD11b (Mac-1 $\alpha)$ & 138 \\
\hline CD11c (leukocyte integrin $\alpha$ subunit) & 139 \\
\hline CD18 (Mac-1 $\beta)$ & 140 \\
\hline $\mathrm{Fc} \gamma \mathrm{R} 1$ & 141 \\
\hline Fc $\gamma$ RIIIA & 142 \\
\hline Mannose receptor & 143 \\
\hline Lyozyme & 144 \\
\hline $\mathrm{IL}-1 \beta$ & 145 \\
\hline Myeloperoxidase (MPO) & 146 \\
\hline$c$-fes/c-fps & 147 \\
\hline CD33 & 148 \\
\hline Proteinase-3 & 149 \\
\hline Neutrophil elastase & 150 \\
\hline $\begin{array}{l}\text { gp91 } 1^{\text {phox }} \text { (phagocyte NADPH oxidase } \\
\text { component) }\end{array}$ & 151 \\
\hline $\begin{array}{l}\text { p47 } 7^{\text {phox }} \text { (phagocyte NADPH oxidase } \\
\text { component) }\end{array}$ & 152 \\
\hline IL-8 receptor (CXCR1) & 153 \\
\hline Eosinophil-derived neurotoxin (RNS2) & 154 \\
\hline $\mathrm{IL}-4$ & 155 \\
\hline SCL/Tal-1 & 156 \\
\hline PU.1 & 40 \\
\hline \multicolumn{2}{|l|}{ Megakaryocyte/Erythrocyte } \\
\hline GPIIb & 157 \\
\hline Platelet basic protein (PBP) & 158 \\
\hline$\beta$-globin (intervening sequence 2) & 55 \\
\hline Glutathion peroxidase & 159 \\
\hline \multicolumn{2}{|l|}{ Virus } \\
\hline EB virus EBNA2 & 160 \\
\hline SV40 & 14 \\
\hline $\begin{array}{l}\text { Equine infectious anemia virus } \\
\text { (Lentivirus) }\end{array}$ & 161 \\
\hline
\end{tabular}

due to absence of expression of GM-CSF receptors. However, this is not true, since early myeloid genes such as GM-CSFR, G-CSFR and MPO are expressed in PU. $1^{-1-}$ embryos and differentiated $P U .1^{-1-}$ ES cells. ${ }^{23}$ In spite of expression of GM- and G-CSFR, PU.1 ${ }^{-1-}$ myeloid progenitors fail to respond to GM- and G-CSF, although the unresponsiveness to G-CSF is bypassed by signaling with IL-3 in vitro. ${ }^{34}$ The expression of genes associated with terminal myeloid differentiation such as $\mathrm{M}$ CSFR and CD11b is eliminated in differentiated $P U .1^{-1-}$ ES cells. PU.1 $1^{-1-}$ mice develop neutrophils but PU.1deficient neutrophils fail to respond to chemokines, do not generate superoxide ions, and are ineffective at bacterial 
uptake and killing. ${ }^{35}$ Therefore, the earliest events in myelopoiesis occur but terminal myeloid differentiation is blocked in the absence of PU.1, suggesting that PU.1 is not essential for commitment to the myeloid cell lineage but is required for normal macrophage and granulocytic differentiation. PU.1 is upregulated during macrophage differentiation. ${ }^{36}$ PU.1 but not other Ets family transcription factors such as Ets-2 or Fli-1 have been shown to be necessary for the M-CSF-dependent proliferation of macrophages. ${ }^{37}$

PU.1 is involved not only in the expression of hematopoietic cell-specific structural genes stated above, but also in commitment from hematopoietic stem cells to various cell lineages. Expression of PU.1 in purified CD34 ${ }^{+}$ cells, multipotent hematopoietic precursors, was upregulated during myeloid differentiation with granulocyte/macrophage-colony-stimulating factor (GM-CSF) but not during erythroid differentiation of these cells with erythropoietin (Epo). ${ }^{38}$ When synthetic oligonucleotides competing for PU. 1 function were added to $\mathrm{CD} 34^{+}$cells in vitro, CFU-GM (granulocyte/macrophage - colony-forming unit) and BFU-E (erythroid burst-forming unit) formation was extensively decreased. Enforced expression of PU.1 in multipotent hematopoietic progenitors induces myeloid lineage commitment probably by suppression of a master regulator of nonmyeloid genes. ${ }^{39}$ These data suggest that PU. 1 is essential during the early phases of both myeloid and erythroid hematopoietic cell commitment.

Analyses of the murine and human PU.1 promoters revealed that PU.1 itself activates its own promoter in an autoregulatory loop. ${ }^{40,41}$ Furthermore, our previous work in somatic cell hybrids suggest that PU.1 expression is programmed to be turned on in specific hematopoietic lineages by release from negative regulation during embryonic cell differentiation. ${ }^{42}$ Full characterization of the transcriptional cascades involved in regulation of $P U .1$ gene expression during development remains to be determined.

\section{Deregulated expression of PU.1 in murine erythroleukemia cells}

As described above, PU.1 is highly expressed in the normal course of B cell and macrophage differentiation. In contrast, the level of PU.1 expression is not so high in normal erythroid cells and appears to be downregulated in erythropoiesis. Thus, by accident, deregulated expression of PU.1 in erythroid cells could possibly result in abnormal cell proliferation and differentiation. Indeed, activation of the PU.1 gene, which is identical to the Spi-1 (spleen focusforming virus proviral integration-1) gene located near the common proviral integration site in MEL cells, ${ }^{43,44}$ is believed to be an important step of murine erthroleukemogenesis induced by inoculation of Friend virus in mice. ${ }^{45}$ Furthermore, infection of mouse long-term bone marrow cultures with a

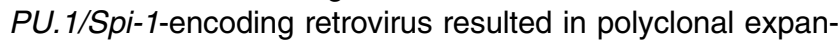
sion of immortalized erythroblasts, although the resulting cell lines still required erythropoietin (Epo) and bone marrow stromal cells for their survival and proliferation. ${ }^{46}$ More direct evidence for deregulated expression of the PU.1 gene in leukemogenesis was provided from the experimental fact that transgenic mice homozygous for the PU.1/Spi-1 gene developed a multistep erythroleukemia with hepato-splenomegaly early after birth. ${ }^{47}$

\section{PU.1 in erythroid differentiation}

Established MEL cells are clonogenic in vitro and tumorigenic in vivo but still have a potential to differentiate into erythrocytelike cells expressing the $\beta$-globin gene when treated with dimethyl-sulfoxide (DMSO) or $\mathrm{N}, \mathrm{N}^{\prime}$-hexamethylene-bisacetamide (HMBA) in vitro. ${ }^{48}$ It is well known that expression of the c-myc and c-myb oncogenes is downregulated during terminal erythroid differentiation and overexpression of these genes inhibits cell differentiation of MEL cells. ${ }^{49,50}$ Expression of the PU.1 gene is also found to be decreased during MEL cell differentiation. ${ }^{51}$ Our results clarified the role of PU. 1 in erythroid differentiation by showing that introduction of a zincinducible expression plasmid of $P U .1$ into MEL cells markedly inhibited induction of the $\beta$-globin gene after treatment with DMSO and $\mathrm{ZnCl}_{2}{ }^{9}{ }^{9} \mathrm{~A}$ similar result was obtained independently by another group using a constitutive expression vector. $^{52}$ Thus, overexpression of PU. 1 inhibits differentiation of MEL cells, suggesting that downregulation of the PU.1 gene is prerequisite for terminal erythroid differentiation. In other words, PU.1 acts as an oncogene to inhibit terminal differentiation in erythroid cells.

Interestingly, the differentiation block was also observed in MEL cells transfected with PU.1 mutants with a deletion in the activation domain but not with a deletion in the Ets domain. ${ }^{9}$ Thus, the activation domain of PU.1 appeared to be dispensable for PU.1-induced differentiation block in MEL cells. Similar results have been reported in the block of TPA-induced monocytic differentiation in v-myb transformed monoblasts, where overexpression of the mutant forms of c-Myb with deleted activation domains can by-pass cell differentiation and cell cycle arrest as effectively as the wild-type. ${ }^{53}$ Furthermore, deletion of the acidic transactivation domain of PU.1 does not affect its ability to promote macrophage development, suggesting that protein-protein interaction may be important during macrophage development. ${ }^{54}$ Transcriptional activities of these factors may not be required to inhibit cell differentiation.

PU.1 binds to the DNase I-hypersensitive intervening sequence 2 in the mouse $\beta$-globin gene to change chromatin structure. ${ }^{55}$ The transferrin receptor is critical for erythroid differentiation and its promoter is activated by Ets-1. ${ }^{56}$ A competitive action of PU.1 against other Ets family proteins on the promoter binding sites of such erythroid-specific genes could be one reason for PU.1induced differentiation block in MEL cells. Enhanced expression of exogenous retinoic acid receptor alpha $(\mathrm{RAR} \alpha)$ and thyroid hormone receptor alpha (TR $\alpha / c$-erbA) in erythroblasts rendered them susptible to modulation of erythroid differentiation by RA and T3. ${ }^{57}$ Functional interference between PU.1 and steroid hormone or vitamin receptors including $R A R \alpha$ and $\operatorname{TR} \alpha$ has been found in reporter assays. ${ }^{58}$ Thus, negative cross-talk between PU. 1 and nuclear hormone receptors acting in the erythroid differentiation pathway seems to be one reason for 
differentiation block. Interaction of PU.1 with coactivator CREB-binding protein (CBP) is a likely molecular mechanism involved in such negative cross-talk, as discussed later.

\section{PU.1 in growth control}

Since the PU.1 gene is an oncogene and it immortalizes erythroblasts, ${ }^{46}$ it has been speculated that overexpression of PU.1 might promote proliferation of cells. When PU.1/Spi-1 gene expression in MEL cells was inhibited by using relatively high doses of antisense oligonucleotides, proliferation and cloning efficiency of the cells were shown to be decreased with about $40 \%$ inhibition. ${ }^{59}$ On the contrary, when the PU.1 level was increased by transfection of MEL cells with a zincinducible PU.1-expression vector, cell growth was unexpectedly reduced in the presence of $\mathrm{ZnCl}_{2} .{ }^{9}$ The growth inhibition appears not to be due to the combined effect of $\mathrm{ZnCl}_{2}$, since growth reduction has also been reported in $M E L$ cells transfected with a constitutive $P U$.1-expression vector. ${ }^{52}$ Similarly, ectopic overexpression of PU.1 in K562, a human myeloid leukemic cell line, significantly reduces the growth rate, with inhibition of erythroid differentiation and promotion of monocytic differentiation. ${ }^{60}$ Although we do not know the reason for these seemingly paradoxical results at present, the expression level of the gene may be critical for these effects. A moderate level of PU.1 expression might be necessary for transformation and deregulated proliferation of proerythroblasts, while a high level of expression may be rather toxic and induce apoptosis as mentioned in the next section. Given the fact that PU. 1 transactivates tissue-specific genes necessary for differentiation of $B$ cells and macrophages, it may be reasonable for PU. 1 to inhibit cell proliferation in the terminal stages of these cell lineages. Thus, it is evident that PU.1 induces growth arrest rather than cell proliferation in some cases. Growth arrest induced by overexpression of PU.1 in MEL cells could be partly explained by decrease in c-myc mRNA and its corresponding protein expression levels. ${ }^{10}$ The c-myc promoter $(-138$ to +517$)$ was found to be a target of downregulation by PU.1 in a dose-dependent manner by luciferase assay (Kihara-Negishi et al, in preparation). Moreover, the activity of the c-myb promoter ( -197 to +204 ) was also found to be decreased in MEL cells in a dose dependent manner when a PU.1-expression vector was cotransfected, consistent with the results reported by others. ${ }^{61}$ Induction of $p 21^{C i p 1}$ gene expression and temporal downregulation of $c-m y c$ and c-myb gene expression by treatment of MEL cells with DMSO ${ }^{62}$ could further augment growth inhibition induced by PU.1 overexpression alone. The possible involvement of c-myc and c-myb in PU.1-induced growth arrest does not exclude the possibility that other transcription factors such as members of the Fos/Jun family are also involved in this effect, since Ets family proteins and AP-1 are critical nuclear targets of Ras-MAP-kinase signaling pathway for cell proliferation. ${ }^{63,64}$ The effect of overexpression of PU.1 on Fos/Jun family expression in MEL cells is so far unknown. Direct physical interactions between Ets family and Jun family transcription factors have been reported $^{65}$ and Fos/Jun family are implicated in cell differentiation, proliferation and apoptosis in several hematopoietic cells. $^{6,67}$

\section{PU.1 in apoptosis}

The growth of MEL cells transfected with a zinc inducible $P U$.1-expression vector was markedly reduced when the cells were treated with DMSO in addition to $\mathrm{ZnCl}_{2}$ and apoptotic cell death was subsequently observed by $48 \mathrm{~h}$ after the treatment. $^{9}$ FACS analyses revealed that accumulation of cells in G0/G1 phase preceded the onset of apoptosis and the apoptosis occurs in G0/G1 through S-phases but not in G2through M-phases. ${ }^{10} \mathrm{~A}$ remarkable decrease in c-myc and $b c /-$ 2 gene expression was noticed in PU.1-transfectants treated with DMSO and $\mathrm{ZnCl}_{2}$, while no significant differences were observed in $b c l-X_{L}$, bax, p21 ${ }^{\text {Cip } 1}$, p53, Fas and Fas-ligand gene expression as compared with their expression kinetics in control cells under the same conditions. ${ }^{10}$ The reduction of the $\mathrm{c}-\mathrm{Myc}$ and $\mathrm{Bcl}-2$ protein levels preceded the induction of apoptosis. PU.1-induced apoptosis was prevented in cells cultured in $30 \%$ serum, where a decrease in c-myc and $b c /-2$ gene expression was not observed. Thus, high concentrations of serum in culture rescues MEL cells from PU.1-induced apoptosis probably through maintaining the expression levels of the c-myc and $b c /-2$ genes. In support of this idea, enforced expression of the c-myc and $b c l-2$ genes in PU.1-transfected cells attenuated apoptosis, if not completely. ${ }^{10}$ In contrast to PU.1-induced differentiation block, PU.1-induced growth arrest and apoptosis required both the activation and the Ets domain of PU.1. This is similar to $\mathrm{c}-\mathrm{Myc}$-induced cell proliferation and apoptosis, in which all of the transactivation domain, the DNA-binding domain and the dimerization domain of c-Myc are necessary. ${ }^{68}$ Thus, transcriptional activation of certain genes by PU. 1 seems to be important for growth arrest and apoptosis. These results also indicate that there was no association between competence for induction of cell differentiation and ability to induce apoptosis by overexpression of PU. 1 in MEL cells. Collectively, overexpression of PU.1 in MEL cells induces apoptosis by a p53- or Fas-independent pathway which is probably mediated by downregulation of $\mathrm{bcl}-$ 2 and/or c-myc gene expression.

Induction of PU.1-induced growth arrest and apoptosis in MEL cells appeared to be closely linked, in contrast with the dissociation between PU.1 induced differentiation block and growth arrest or apoptosis. ${ }^{9}$ Overexpression of PU.1, or treatment with DMSO alone, induced moderate and slight inhibition of proliferation in MEL cells, and both were needed to induce growth arrest and apoptosis. Severe growth inhibition may be a trigger for PU.1-induced apoptosis. Apoptosis may be induced by mitotic catastrophe due to insufficient sets of effectors for cell cycle progression. ${ }^{69}$

\section{c-Myc-/c-Myb-induced apoptosis}

c-Myc has been shown to harbor both mitogenic and apoptotic properties. $^{70}$ Involvement of $\mathrm{c}-\mathrm{Myc}$ in the induction of apoptosis has been reported in several cell systems. For example, inappropriate overexpression of c-myc following deprivation of growth factors, promotes apoptosis in myeloid progenitor cells ${ }^{71}$ and in fibroblasts. ${ }^{8}$ T-cell receptor-mediated apoptosis in immature $T$ cells is also associated with induction of c-myc expression and is abrogated by addition of c-myc 
antisense oligonucleotides to the cells. ${ }^{72}$ In these cases, overexpression of $\mathrm{c}-\mathrm{Myc}$ is a trigger for the onset of apoptosis. In contrast to these reports, the recent growing evidence suggests that a drop in c-myc expression induces apoptosis in hematopoietic cell systems. For example, treatment of B-cell lines with anti-IgM antiserum or TGF $\beta$ results in a dramatic decline in c-myc expression due to a reduction of DNA binding by $\mathrm{NF} \kappa \mathrm{B} / \mathrm{Rel}$ family transcription factors to its promoter, and subsequently leads to growth inhibition and activation of apoptosis of the cells. ${ }^{73,74}$ Recently, it has reported that $\mathrm{NF} \kappa \mathrm{B} / \mathrm{Rel}$ family transcription factors positively regulate expression of the prosurvival $b c /-2$ homolog $A 1 / b f l-1$ gene $^{75}$ that is critical for the control of cell survival during lymphocyte activation. ${ }^{76}$ Ectopic expression of Blimp-1, a plasmacytoma repressor factor, represses endogenous C-Myc by binding to the c-myc promoter and causes apoptosis in B cells. ${ }^{77}$ This apoptosis can be partially overcome by ectopic expression of $c-M y c$. Furthermore, suppression of c-myc is also a critical step in glucocorticoid-induced apoptosis in a T cell leukemia line. ${ }^{78}$ In these cases, an extensive drop in c-Myc expression is a trigger of onset of apoptosis. Downregulation of c-Myc expression in PU.1-induced apoptosis falls in this category. Expression of c-myc is generally consistent with the proliferative rate of cells and it is activated by stimulation by mitogens or growth factors. Erythropoietin (Epo) regulates growth and survival of erythroid cells by increasing c-myc transcripts by a protein kinase C-dependent pathway. ${ }^{79}$ Proliferation of Friend virus-infected pre-leukemic proerythroblasts at an early stage is dependent on Epo, and depletion of the factor leads to apoptotic cell death. ${ }^{46}$ Since growth of the MEL cells we used is Epo-independent, and there was no change in Epo receptor gene expression even after PU.1 overexpression (Kondoh et al, unpublished observations), continuous activation of the c-myc gene must have occurred without any stimulation of Epo in this cell line. Thus, downregulation of c-myc expression in Epo-independent line may lead to a situation similar to Epo deprivation in Epodependent cell lines.

c-Myb transactivates the promoters of the c-myc and $b c /-$ 2 genes in various hematopoietic cell lines, ${ }^{80,81}$ and downregulation of $c-m y b$ also leads to apoptosis in several systems. The dramatic growth arrest and reduction of cell number in c-myb antisense-transfected neuroblastoma cells has been reported to be due to the induction of apoptosis ${ }^{82}$ and downregulation of $c-m y b$ is associated with apoptosis in $\mathrm{T}$ cells. ${ }^{83}$ As previously mentioned, we found that the activities of the $c-m y c$ and $c-m y b$ promoters were negatively regulated by overexpression of PU.1 in MEL cells. Since there are several putative Ets-binding sites (EBS) in the c-myc and c-myb promoters ${ }^{84}$ and in the $b c /-2$ promoter, ${ }^{85}$ a competitive action of PU.1 against Ets-1/Ets2 at the EBS might influence promoter activities. Experiments are being performed in our laboratory to elucidate the precise molecular mechanisms of the suppression of these promoter activities.

\section{GATA-1 and apoptosis}

Several hematopoietic transcription factors, including GATA1, NF-E2, SCL/Tal-1, EKLF and LOM2/Rnbt2, are required for erythroid development and differentiation. ${ }^{1}$ Targeted disruption of the GATA-1 gene leads to impairment of erythropoiesis in mice. ${ }^{86}$ GATA-1 negative embryonic stem (ES) cells fail to differentiate into mature erythroid cells and GATA-1 negative erythroid precursors undergo apoptosis. ${ }^{87}$ These reports suggest that survival as well as differentiation of erythroid cells is maintained by hematopoietic transcription factors. ${ }^{1}$

We found that GATA-1-DNA but not NF-E2-DNA complex formation as judged by EMSA was markedly reduced in $P U .1$-transfected cells by $32 \mathrm{~h}$ after treatment with DMSO and $\mathrm{ZnCl}_{2}$ just when apoptosis started, though a prominent GATA-1 signal was detected in Northern and Western blot analyses in the transfectants comparable to that in mock-transfectants under the same conditions. ${ }^{12}$ The reduced DNA binding of GATA-1 in PU.1-transfectants undergoing apoptosis was not due to a decreased level nor a change in subcellular localization of GATA-1 protein as found in avian erythroid differentiation. ${ }^{88}$ The reduced DNAbinding activity of GATA-1 was restored when PU.1induced apoptosis was counteracted by adding $30 \%$ serum to the culture medium. Treatment of nuclear extracts from MEL cells undergoing apoptosis with alkaline phosphatase did not restore the DNA-binding activity of GATA-1, consistent with the report that the phosphorylation state of GATA-1 does not significantly influence its DNA-binding activity. ${ }^{89}$ Interestingly, the DNA-binding activity of GATA-1 in parental MEL cells was abolished by premixing with the same amounts of nuclear extracts from PU.1-transfected MEL cells but not from the parental cells cultured with DMSO and $\mathrm{ZnCl}_{2}$ for $48 \mathrm{~h}$. Thus, an inhibitory factor(s) which interacts with GATA-1 and prevents it from binding to DNA might be induced or become active in the apoptotic process. In line with this, it has been shown that estrogeninduced apoptosis of MEL cells is accompanied by inhibition of GATA-1 activity. ${ }^{90}$ Downregulation of $D L X-7$ homeobox gene expression results in a reduction of GATA1 and c-myc mRNA levels, with an accompanying induction of apoptosis in a human myeloid leukemic cell line K562. ${ }^{91}$ Thus, PU.1 may participate in cell proliferation and apoptosis by modulating other transcription factors that play key roles in apoptosis.

\section{Interaction of PU.1 with other proteins}

PU.1 may indirectly affect expression of several genes critical for differentiation, proliferation and apoptosis by interacting with other proteins, since the activation domain at the $\mathrm{N}$ terminus of PU. 1 has been shown to interact in vitro with the conserved $\mathrm{C}$-terminal domain of the basal transcription factor TFIID and the 'pocket' domain of the tumor suppressor retinoblastoma $(\mathrm{Rb})$ protein. ${ }^{92}$ Furthermore, the C-terminal region of PU.1 has been reported to interact with the leucine zipper transcription factor NF-IL6 $\beta$ (C/EBP $\delta)$, the DNAbinding protein $\mathrm{HMG} \mathrm{I} / \mathrm{Y}$, the multi-functional phosphatase MKP-1 and the chaperone protein HSP 90. ${ }^{93}$ PU.1 also binds to the potential splicing factors p54 ${ }^{\text {nrb }}$ (nuclear RNA-binding protein $54 \mathrm{kDa}$ ) and TLS (translocated in liposarcoma)/ FUS, a gene related to EWS (Ewing's sarcoma). ${ }^{94,95}$

We recently found that a portion of the transcriptional activation domain (a.a. 74-122) of PU.1 directly interacted 
with the region spanning residues $1283-1915$ of the CREB binding protein (CBP), overlapping with the adenovirus E1A-binding site. ${ }^{13} \mathrm{CBP}$ and the related protein $\mathrm{p} 300$ have been reported to interact with a variety of transcription factors, including CREB, AP-1 (Fos/Jun), c-Myb, nuclear hormone receptors (NHRs), STATs, NF $\kappa$ B, E2F-1 and p53, as well as viral oncoproteins like E1A and SV40 large Tantigen. ${ }^{96,97}$ p300/CBP serves as a transcriptional adaptor for several transcription factors ${ }^{98}$ by direct bridging between basal transcription factors and several sequence-specific transcriptional activators. p300/CBP itself and the cellular p300/CBP associated factor (P/CAF) possess intrinsic histone acetyltransferase (HAT) activities. ${ }^{99,100}$ Given the good correlation between acetylation of core histones and transcriptional activity, it is speculated that the HAT activity of $\mathrm{P} / \mathrm{CAF}$ and/or $\mathrm{p300/CBP}$ is responsible for regulation of chromatin configuration. ${ }^{101}$ Beside histones, p300/CBP can directly modify the C-terminal domain of the p53 tumor suppressor protein and the DNA binding domain of the erythroid transcription factor GATA-1 by acetylation to stimulate their DNA binding activities. ${ }^{102,103}$ It has been reported that $\mathrm{CBP}$ is required for differentiation of muscle and $B$ cells, and inhibition of $C B P$ function by $E 1 A$ viral oncoprotein blocks cell differentiation. ${ }^{104}$ Furthermore, CBP has been reported recently to interact with two other hematopoietic transcription factors important for erythroid differentiation, Ets $-1^{99}$ and GATA- $1^{90}$, through the region overlapping with the PU.1 binding site. Since CBP is a shared coactivator for several transcription factors within cells, ${ }^{105}$ functional interference between AP-1 and NHRs has been proposed to be a result of competition for limiting amounts of CBP in cells. ${ }^{106}$ By analogy to this, it is tempting to speculate that sequestration of a limiting amount of CBP by a large amount of PU.1 could decrease the interactions of CBP with erythroid differentiation- and/or survival-promoting transcription factors, such as GATA$1,{ }^{107}$ Ets- $1^{108,56}$ and NHRs, ${ }^{109}$ in PU.1-overexpressing MEL cells, and subsequently lead to erythroid differentiation block, growth arrest and apoptosis. Indeed, a mutual antagonistic effect has been reported between PU.1 and NHRs, although there is no direct physical contact between two. ${ }^{58}$ We are currently in the process of substantiating the involvement of CBP in cell differentiation, proliferation and apoptosis of MEL cells.

\section{Concluding remarks}

In this review, we have briefly summarized the functional role of PU. 1 in normal $B$ and myeloid cell proliferation and differentiation. We have also described how overexpression of PU.1 in murine erythroleukemia (MEL) cells in conjunction with DMSO induces differentiation block, growth arrest and apoptosis, and have discussed possible molecular mechanisms for these effects. The precise molecular mechanisms of the PU.1-induced cellular effects in MEL cells are still obscure. However, a simple scheme of the pathways and relevant molecules involved in PU.1-induced differentiation block, growth arrest and apoptosis as understood at present is illustrated in Figure 1. ${ }^{9-13,58,90}$

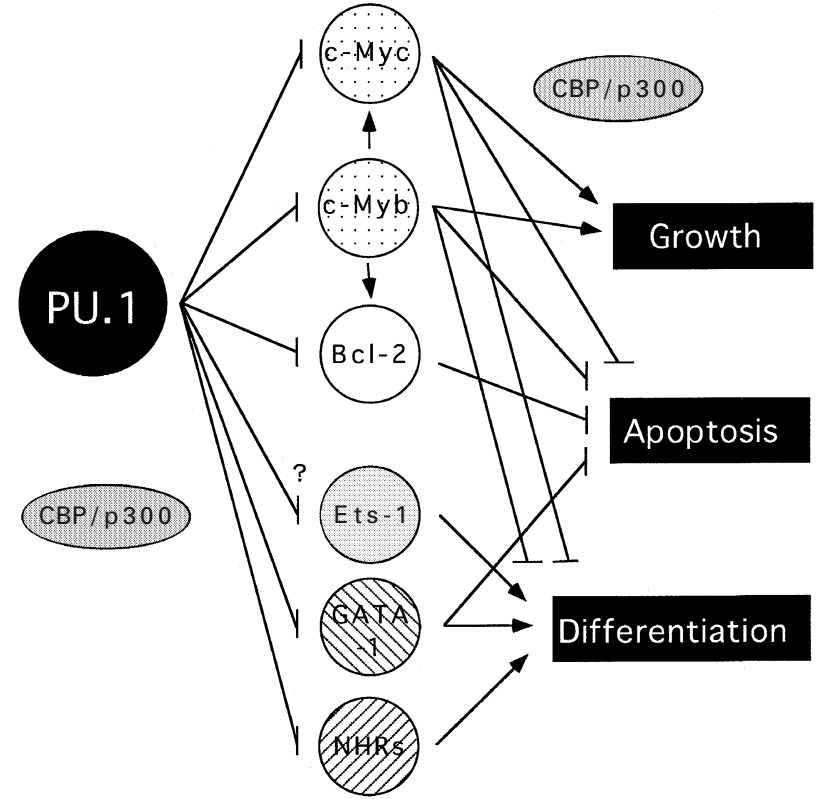

Figure 1 Schematic representation of the possible cross talk between transcription factors for PU.1-induced cellular effects in erythroid cells. For the sake of simplicity, only representative signal transduction pathways and relevant transcription factors are shown. $\rightarrow$ : production, $-\mid$ : inhibition CBP:CREB binding protein, NHRs: nuclear hormone receptors

It is not so surprising that PU.1 induces apoptotic cell death, considering that many oncogenes and tumor suppressor genes are involved in apoptosis as well as malignant transformation in hematopoietic cells. ${ }^{5}$ The c-myc oncogene can induce both proliferation and apoptosis but its net effect depends upon the status of other components within the cell. This is also true for the ras oncogene. Activated Ras induces growth arrest rather than cell proliferation by inducing cyclin-dependent kinase (CDK) inhibitor $\mathrm{p} 21^{\mathrm{Cip} 1}$, when the signal through Ras-related GTPase Rho is inhibited. On the other hand, when Rho is active, induction of $\mathrm{p} 21^{\mathrm{Cip} 1}$ by Ras is suppressed and Ras induces DNA synthesis. ${ }^{110}$ Although over-expression of PU.1 induced growth inhibition in MEL cells, it did not induce growth inhibition in a fibrosarcoma cell line grown in liquid culture, ${ }^{11}$ suggesting that PU.1-induced growth arrest and apoptosis might be cell type-specific. Alternatively, PU.1 may exert different effects in different cellular states, which may explain why high levels of expression of PU.1 are not toxic in normal B cells and macrophages/ neutrophils.

More complicated is the fact that both overexpression and downregulation of the c-myc gene can induce apoptosis in cells. This may suggest that not only cellular state and cell background, but also expression levels of the oncogenes, influence the net effects. The effects of c-Myc on other factors regulating the cell cycle and apoptosis may be different with low and high dose expression. In this context, it has been reported that moderate Raf activity induces DNA synthesis by inducing cyclin D expression, while a high-intensity Raf signal causes cell cycle arrest through induction of p21 cip1 111 
or p16 ${ }^{\text {INK4a }} 112$ Similarly, whether PU.1 induces growth arrest or not might be decided by its expression level in cells.

Apoptosis is believed to play an important role in eliminating unwanted cells which have a potential to easily become malignant cells. In this sense, apoptosis induced by overexpression of oncogenes might be a cellular failsafe system to prevent malignant transformation as well as apoptosis induced by tumor suppressor genes. ${ }^{113}$ Cancer cells seem to arise by sneaking through such a subtle balance in cells, where both overexpression and low dose expression of oncogenes are not effective to transform cells. This may explain the seemingly discrepant cellular effects of PU.1 on cell transformation, growth arrest and apoptosis. The tumor suppressor gene p53 is believed to be a safe guardian in development of mouse erythroleukemias $^{45}$ as well as most human tumors. ${ }^{114}$ This notion is supported by the facts that the p53 gene is often inactivated by viral integration or mutation in most MEL cells ${ }^{115}$ and that introduction of the wild-type p53 gene into MEL cells induces apoptosis. ${ }^{116}$ A mutated p53 gene in tumor cells facilitates escape from apoptosis. In our study, however, accumulation of p53 was not observed in PU.1overexpressing MEL cells, indicating that PU.1-induced apoptosis is p53-independent. ${ }^{10}$

Other Ets family members are also implicated in cell proliferation and apoptosis. Fli-1 is a member of the Ets family of transcription factors also implicated in MEL genesis, ${ }^{117}$ and transcription of the Fli-1 gene is positively regulated by PU.1. ${ }^{118}$ The Fli-1 gene is rearranged with the EWS gene in the development of human Ewing sarcomas by specific chromosomal translocation. ${ }^{119}$ Expression of Fli1 as well as EWS-Fli-1 promotes cell proliferation and inhibits apoptosis. ${ }^{120}$ Introduction of a retroviral construct expressing Fli-1 into K562 cells reduces the growth rate of the cells and causes induction of megakaryocytic and erythroid differentiation. ${ }^{121}$ Furthermore, overexpression of Fli-1 in MEL cells did not induce significant growth arrest and apoptosis (Matsumoto et al, in preparation), suggesting that PU.1 and Fli-1 exert different cellular effects in spite of their involvement in MEL genesis, and that the PU.1induced cellular effects mentioned above are not mediated through Fli-1. Ectopic expression of Ets-1 reduces tumorigenicity of human colon cancer cell lines, due to its ability to induce apoptosis. ${ }^{122}$ These results suggest that the ets-family oncogenes are involved not only in important steps of cell differentiation and proliferation but also in antiproliferative and apoptotic processes under certain circumstances.

Finally, our results, taken together with other reports, support the complicated but interesting notion that oncogenes sometimes act like tumor suppressor genes ${ }^{123}$ or induce cell differentiation, ${ }^{124}$ growth inhibition, ${ }^{110}$ senescence $^{112}$ and apoptosis, ${ }^{8}$ depending on cellular conditions. Thus, the function of molecules has to be defined not by itself but as mutual interactions with other molecules in cells. Although the precise molecular mechanisms have still to be resolved, PU.1-induced effects in MEL cells may serve as a useful system to answer to such complex problems.

\section{Acknowledgements}

Drs. F. Moreau-Gachelin, R.A. Maki, D. Kabat, T. Papas, M. Obinata, S. Cory, B. Carabretta and R.H. Goodman are acknowledged for their kind cooperation in donation of the plasmids and/or antibodies used in the series of our studies. Our works presented here were supported by Grants-in-Aid for Scientific Research from the Ministry of Education, Science and Culture of Japan, and grants from the Uehara Foundation, Tokyo, The Vehicle Racing Commemorative Foundation, Tokyo, Taiho Pharmaceutical Co. Ltd., Saitama, and from OB-GYN Akiyama Memorial Hospital, Hakodate, Japan.

\section{References}

1. Shivdasani RA and Orkin SH (1996) The transcriptional control of hematopoiesis. Blood 87: 4025-4039

2. Tenen DG, Hromas R, Licht JD and Zhang D-E (1997) Transcription factors, normal myeloid development, and leukemia. Blood 90: 489-519

3. Sawyer CL, Denny CT and White ON (1991) Leukemia and disruption or normal hematopoesis. Cell 64: 337-350

4. Look AT (1995) Oncogenic role of 'master' transcription factors in human leukemias and sarcomas: A developmental model. Adv. Cancer Res. 67: 2557

5. Harrington EA, Fanidi A and Evan GI (1994) Oncogenes and cell death. Curr. Opin. Genet. Dev. 4: 120-129

6. BlackwoodEM, LüscherB and Eisenmann RN (1992) Myc and Max associate in vivo. Genes Dev. 6: 71-80

7. Lemaitre J-M, Buckle RS and Méchali M (1996) c-Myc in the control of cell proliferation and embryonic development. Adv. Cancer Res. 70: 95-144

8. Evan GI, Wyllie AH, Gilbert CS, Littlewood TD, Land H, Brook M, Walters CM, Penn LZ and Hancock DC (1992) Induction of apoptosis in fibroblasts by c-myc protein. Cell 69: 119-128

9. Yamada T, Kondoh H, Matsumoto M, Yoshida M, Maekawa A and Oikawa T (1997) Overexpression of PU.1 induces growth and differentiation inhibition and apoptotic cell death in murine erythroleukemia cells. Blood 89: 1383-1393

10. Kihara-Negishi F, Yamada T, Kubota Y, Kondoh N, Yamamoto H, Abe M, Shirai T, Hashimoto Y and Oikawa T (1998) Down-regulation of c-mycand bcl-2 gene expression in PU.1-induced apoptosis in murine erythroleukemia cells. Int. J. Cancer 76: $523-530$

11. Kondoh N, Yamada T, Kihara-Negishi F, Yamamoto H and Oikawa T (1998) Enhanced expression of the urokinase-type plasminogen activator gene and reduced colony formation in soft agar by ectopic expression of PU. 1 in HT1080 human fibrosarcoma cells. Brit. J. Cancer 78: 718-723

12. Yamada T, Kihara-Negishi $F$, Yamamato $H$, Yamamato $M$, Hashimoto $Y$ and Oikawa T (1998) Reduction of DNA binding activity of the GATA-1 transcription factor in the apoptotic process induced by overexpression of PU.1 in murine erythroleukemia. Exp. Cell Res. 245: 186-194

13. Yamamoto H, Kihara-Negishi F, Yamada T, Hashimoto Y and Oikawa T (1999) Physical and functional interactions between the transcription factor PU.1 and the coactivator CBP. Oncogene 18: 1495-1501

14. Klemsz JM, McKercher SR, Celada A, Beveren CV and Maki RA (1990) The macrophage and $B$ cell-specific transcription factor PU.1 is related to the ets oncogene. Cell 61: 113-124

15. Janknecht R and Nordheim A (1993) Gene regulation by Ets proteins. Biochim. Biophys. Acta 1155: $346-356$

16. Moreau-Gachelin F(1994) Spi-1/PU.1: an oncogene of the Ets family. Biochim. Biophys. Acta 1198: 149-163

17. Bassuk AG and Leiden JM (1997) The role of Ets transcription factors in development and function of the mammalian immune system. Adv. Immunol. 64: $65-104$

18. Kondandapani R, Pio F, Ni C-Z, Piccialli G, Klemsz M, McKercher S, MakiR and Ely KR (1996) A new pattern for helix-turn-helix recognition revealed by the PU.1 Ets-domain-DNA complex. Nature 380: 456-459

19. Scott EW, Simon MC, Anastasi J and Singh H (1994) Requirement of transcription factor PU.1 in the development of multiple hematopoietic lineages. Science 265: 1573-1577 
20. McKercher SR, Torbett BE, Anderson KL, Henkel GW, Vestal DJ, Baribault H, Klemsz M, Feeney AJ, Wu GE, Paige CJ and Maki RA (1996) Target disruption of the PU. 1 gene results in multiple hematopoietic abnormalities. EMBO J. 15: $5647-5658$

21. Glimcher LH and Singh H (1999) Transcription factors in lymphocyte development $-T$ and $B$ cells get together. Cell 96: 13-23

22. Henkel GW, McKercher SR, Yamamoto H, Anderson KL, Oshima RG and Mak RA (1996) PU.1 but not ets-2 is essential for macrophage development from embryonic stem cells. Blood 88: 2917-2926

23. Olson M, Sccott EW, Hack A, Su G, Singh H and Simon MC (1995) PU. 1 is not essential for early myeloid gene expression but is required for terminal myeloid differentiation. Immunity 3: 703-714

24. ScottEW, FisherRC, Olson MC, Kehrli EW, Simon MC and Singh H(1997)PU.1 functions in a cell-autonomous manner to control the differentiation of multipotential lymphoid-myeloid progenitors. Immunity 6: 437-447

25. Tondravi MM, McKercher SR, Anderson K, Erdmann JM, Quiroz M, Maki R and Teitelbaum SL (1997) Osteopetrosis in mice lacking hematopoietic transcription factor PU.1. Nature 386: $81-84$

26. Nelsen B, Tian G, Erman B, Gregoire J, Maki R, Graves B and Sen R (1993) Regulation of lymphoid-specific immunoglobulin $\mu$ heavy chain gene enhancer by Ets-domain proteins. Science 261: $82-86$

27. Erman B, Cortes M, Nikolajczyk BS, Speck NA and Sen R (1998) ETS-core binding factor: a common composite motif in antigen receptor gene enhancers. Mol. Cell. Biol. 18: 1322-1330

28. Pongubala JMR and Atchison ML (1997) PU.1 can participate in an active enhancer complex without its transcriptional activation domain. Proc. Natl. Acad. Sci. USA. 94: 127-132

29. Hayashi R, Takemori T, Kodama M, Suzuki M, Tsuboi A, Nagawa F and Sakano $\mathrm{H}$ (1997) The PU.1 binding site is a cis-element that regulates pro-B/pre-B specificity of $\mathrm{V}_{\kappa}-\mathrm{J}_{\kappa}$ joining. J. Immunol. 159: $4145-4149$

30. Eisenbeis CF, Singh H and Strob U (1995) Pip, a novel IRF family member, is a lymphoid-specific, PU.1-dependent transcriptional activator. Genes Dev. 9: 1377-1378

31. Brass AL, Kehrli E, Eisenbeis CF, Storb U and Singh H (1996) Pip, a lymphoidrestricted IRF, contains a regulatory domain that is important for autoinhibition and ternary complex formation with the Ets factor PU.1. Genes Dev. 10: 13352347

32. Himmelmann A, Riva A, Wilson GL, Lucas BP, Thevenin C and Kehrl H (1997) PU.1/Pip and basic helix loop helix zipper transcription factors interact with binding sites in the CD20 promoter to help confer lineage- and stage-specific expression of CD20 in B lymphocytes. Blood 90: 3984-3995

33. Simon MC, Olson M, ScottE, Hack A, Su Gand Singh H(1996) Terminal myeloid gene expression and differentiation requires the transcription factor PU.1. Curr. Topic Mirobiol. Immunol. 211: 113-119

34. DeKoter RP, Walsh JC and Singh H (1998) PU.1 regulates both cytokinedependent proliferation and differentiation of granulocyte/macrophage progenitors. EMBO J. 17: 4456-4468

35. Anderson KL, Smith KA, Pio F, Torbett BE and Maki RA (1998) Neutrophils deficient in PU.1 do not terminally differentiate or become functionally competent. Blood 92: 1576-1585

36. Chen H-M, Zhang P, Voso MT, Hohaus S, Gozalez DA, Glass CK, Zhang D-E and Tenen DG (1995) Neutrophils and monocytes express high levels of PU.1 (Spi-1) but not Spi-B. Blood 85: 2918-2928

37. Celada A, BorràsFE, Soler C, Lloberas J, Klemsz M, van Beveren C, McKercher S and Maki RA (1996) The transcription factor PU.1 is involved in macrophage proliferation. J. Exp. Med. 184: 61-69

38. Voso MT, Burn TC, Wulf G, Lim B, Leone G and Tenen DG (1994) Inhibition of hematopoesis by competitive binding of transcription factor PU.1. Proc. Natl. Acad. Sci. USA. 91: $7932-7936$

39. Nerlov C and Graf T (1998) PU.1 induces myeloid lineage commitment in multipotent hematopoietic progenitors. Genes Dev. 12: 2403-2412

40. Chen H-M, Ray-Gallet D, Zhang P, Hetherington CJ, Gonzalez DA, Zhang D-E, Moreau-Gachelin F and Tenen DG (1995) PU.1 (Spi-1) autoregulates its expression in myeloid cells. Oncogene 11: 1549-1560

41. Chen H-M, Zhang P, Radomska HS, Hetherington CJ, Zhang D-E and Tenen DG (1996) Octamer binding factors and their coactivator can activate the murine PU.1(spi-1) promoter. J. Biol. Chem. 271: 15743-15752

42. Hitomi Y, Yamada T and Oikawa T (1993) Extinction of the PU.1/Sfpi-1 putative oncogene encoding a B cell- and macrophage-specific transcription factor in somatic cell hybrids. Cancer Res. 53: 5759-5765
43. Moreau-Gachelin F, Travitian A and Tambourin $P$ (1988) Spi-1 is a putative oncogene in virally induced murine erythroleukemias. Nature 331: 277-280

44. Paul R, Schuetze S, Kozak S and Kabat D (1989) A common site for immortalizing proviral intergrations in Friend erythroleukemia: molecular cloning and characterization. J. Virol. 63: 4958-4961

45. Ben-David Y and Bernstein A (1991) Friend virus-induced erythroleukemia and the multistage nature of cancer. Cell 66: $831-834$

46. Schuetze S, Stenberg PE and Kabat D (1993) The Ets-related transcription factor PU.1 immortalizes erythroblasts. Mol. Cell. Biol. 13: 5670-5678

47. Moreau-Gachelin F, Wendling F, Molina T, Denis N, Titeux M, Grimber G, Briand P, Vainchenker W and Tavitian A (1996) Spi-1/PU.1 transgenic mice develop multistep erythroleukemias. Mol. Cell. Biol. 16: 2453-2463

48. Friend C, Scher W, Holland JG and Sato T (1971) Hemoglobin synthesis in murine virus-induced leukemic cells in vitro: stimulation of erythroid differentiation by dimethyl sulfoxide. Proc. Natl. Acad. Sci. USA. 68: 378-382

49. Dimitrovsky E, KeuhI WM, Hollins GF, Kirsch IR, Bender TP and Segal S (1986) Expression of a transfected human c-myc oncogene inhibits differentiation of a mouse erythroleukemia cell line. Nature 322: 748-750

50. Todokoro K, Watson RJ, Higo H, Amanuma H, Kuramochi S, Yanagisawa Hand Ikawa $Y(1988)$ Down-regulation of c-myb gene expression is a prerequisite for erythropoietin-induced erythroid differentiation. Proc. Natl. Acad. Sci. USA 85: 8900-8904

51. Schuetze S, Paul R, Gliniak BC and Kabat D (1992) Role of the PU.1 transcription factors in controlling differentiation of Friend erythroleukemia cells. Mol. Cell. Biol. 12: 2967-2975

52. Rao G, Rekhtman N, Cheng G, Krasikov T and Skoulchi Al (1997) Deregulated expression of the PU.1 transcription factor blocks murine erythroleukemia cell terminal differentiation. Oncogene 14: 123-131

53. Engelke U, Smarda J and Lipsick JS (1995) By-pass of TPA-induced differentiation and cell cycle arrest by the c-Myb DNA-binding domain. Oncogene 11: 735-741

54. Fisher RC, Olson MC, Pongubala JMR, Perkel JM, Atchison ML, Scott EW and Simon MC (1998) Normal myeloid development requires both the glutaminerich transactivation domain and the PEST region of transcription factor PU. 1 but not the potent acidic transactivation domain. Cell. Biol. 18: 4347-4357

55. Galson DL, Hensold JO, Bishop TR, Schalling M, D'Andrea, AD, Jones C, Auron $\mathrm{PE}$ and Housman DE (1993) Mouse $\beta$-globin DNA-binding protein B1 is identical to a proto-oncogene, the transcription factor Spi-1/PU.1, and is restricted in expression to hematopoietic cells and the testis. Mol. Cell. Biol. 13: 2929-2941

56. Sieweke M, Tekotte H, Frampton J and Graf T (1996) MafB is an interaction partner and repressor of Ets-1 that inhibits erythroid differentiation. Cell 85:49 60

57. Schroeder C, Gibson L, Zenke M and Beug H (1992) Modulation of normal erythroid differentiation by the endogenous thyroid hormone and retinoic acid receptors: a possible target for v-erbA oncogene. Oncogene 7: 217-227

58. Gauthier J-M, Bourachot B, Doucas V, Yaniv M and Moreau-Gachelin F (1993) Functional interference between the Spi-1/PU.1 oncoprotein and steroid hormone or vitamin receptors. EMBO J. 12: 5089-5096

59. Delgado MD, Hallier M, Meneceur P, Tavitian A and Moreau-Gachelin F (1994) Inhibition of Friend cells proliferation by spi- 1 antisense oligodeoxynucleotides. Oncogene 9: 1723-1727

60. Delgado MD, Gutiérrez P, Richard C, Cuadrado A, Moreau-Gachelin, F. and León J (1998) Spi-1/PU.1 proto-oncogene induces opposite effects on monocytic and erythroid differentiation of K562 cells. Biochem. Biophys. Res. Commun. 252: 383-391

61. Bellon T, Perrotti D and Calabretta B (1997) Granulocytic differentiation of normal hematopoietic precursor cells induced by transcriptional factor PU.1 correlates with negative regulation of the c-myb promoter. Blood 90: 18281839

62. Ponzio G, LoubatA, RochetN, Turchi L, Rezzonico R, FarDF, Dulic V and Rossi B (1998) Early G1 growth arrest of hybridoma B cells by DMSO involves cyclin D2 inhibition and p21 ${ }^{\mathrm{Cip}}$ induction. Oncogene 17: 1159-1166

63. Langer S, Borter DM, Roussel M, Sherr CJ and Ostrowski MC (1992) Mitogenic signaling by colony-stimulating factor 1 and ras is suppressed by the ets-2 DNA-binding domain and restored by myc overexpression. Mol. Cell Biol. 12: 5355-5362

64. Wasylyk B, Hagman J and Gutirrez-Hartmann A (1998) Ets transcription factors: nuclear effectors of the Ras-MAP-kinase signaling pathway. Trends Biochem. Sci. 23: 213-216 
65. Bassuk AG and Leiden JM (1995) A direct physical association between ETS and AP-1 transcription factors in normal human T cells. Immunity 3: 223-237

66. Lieberman DA and Hoffmam B (1998) MyD genes in negative growth control. Oncogene 17: 3319-3329

67. Jacobs-Helber SM, Wickrema A, Birrer MJ and Sawyer ST (1998) AP1 regulation of proliferation and initiation of apoptosis in erythropoietindependent erythroid cells. Mol. Cell. Biol. 18: 3699-3707

68. Amati B and Land H (1994) Myc-Max-Mad: a transcription factor network controlling cell cycle progression, differentiation and death. Curr. Opin. Genet. Dev. 4: $102-108$

69. Packham G and Cleveland JL (1995) c-Myc and apoptosis. Biochim. Biophys. Acta 1242: 11-28

70. Dang CV (1999) c-Myc target genes involved in cell growth, apoptosis, and metabolism. Mol. Cell. Biol. 19: 1-11

71. Askew DS, Ashmun RA, Simmons BC and Cleveland JL (1991) Constitutive cmyc expression in an IL-3 dependent myeloid cell line suppresses cell cycle arrest and accelerates apoptosis. Oncogene 6: 1915-1922

72. Shi Y, Glynn JM, Guilbert LJ, Cotter TG, Bissonnette RP and Green DR (1992) Role of c-myc in activation induced-apoptotic cell death in T-cell hybridoma. Science 257: 212-214

73. Wu M, Lee H, Bellas RE, FitzGerald MJ, Lee H, Schauer SL, Sherr DH and Sonenshein GE (1996) Inhibition of c-myc expression induces apoptosis in WEHI231 murine B cells. Mol. Cell. Biol. 16: 5015-5025

74. Kaptein JS, Lin .C-KE, Wang L, Nguyen TT, Kalunta CI, Park E, Chen F-S and Lad PM (1996) Anti-IgM-mediated regulation of c-myc and its possible relation ship to apoptosis. J. Biol. Chem. 271: 18875-18884

75. Reed JC (1998) Bcl-2 family proteins. Oncogene 17: 3225-3236

76. GrumontRJ, Rourke IJ and Gerondakis S (1999) Rel-dependent induction of A1 transcription is required to protect $B$ cells from antigen receptor ligation-induced apoptosis. Genes Dev. 13: 400-411

77. Lin Y, Wong K and Calame K (1997) Repression of c-myc transcription by Blimp-1. an inducer of terminal B cell differentiation. Science 276: 596-599

78. Thulasi B, Harbour DV and Thompson EB (1993) Suppression of c-myc is a critical step in glucocorticoid-induced human leukemic cell lysis. J. Biol. Chem. 268: $18306-18312$

79. SpanglerR, Bailey SC and Sytkowski AJ (1991) Erythropoietin increases c-myc mRNA by a protein kinase C-dependent pathway. J. Biol. Chem. 266:681-684

80. Cogswell JP, Cogswell PC, Kuehl WM, Cuddihy M, Bender TM, Engelke U Marcu KB and Ting JPY (1993) Mechanism of c-myc regulation by c-myb in different cell lineages. Mol. Cell. Biol. 13: 2858-2869

81. Frampton J, Ramqvist T and Graf T (1996) v-Myb of E26 leukemia virus upregulates $b c /-2$ and suppresses apoptosis in myeloid cells. Genes Dev. 10: $2720-2731$

82. Piacentini M, Rashella G, Calabretta B and Melino G (1994) c-myb downregulation is associated with apoptosis in human neuroblastoma cells. Cell Death Diff. 1: $85-92$

83. Taylor D, Badiani P and Weston K (1996) A dominant interfering Myb mutant causes apoptosis in T cell. Genes Dev. 10: 2732-2744

84. Roussel MF, Davis JN, Cleveland JL, Chysdael J and Hiebert SW (1994) Dual control of myc expression through a single DNA binding site targeted by ets family proteins and E2F-1. Oncogene 9: 405-415

85. Chen $\mathrm{H}-\mathrm{M}$ and Boxer LM (1995) $\pi 1$ binding sites are negative regulators of bcl-2 expression in pre-B cells. Mol. Cell. Biol. 15: 3840-3847

86. Pevny L, Simon MC, Robert E, Klein W, Tsai S-H, D'Agati VD, Orkin SH and Costantini $F$ (1991) Erythroid differentiation in chimeric mice blocked by a targeted mutation in the gene for transcription factor GATA-1. Nature 349: $257-260$

87. Weiss MJ and Orkin SH (1995) Transcription factor GATA-1 permits surviva and maturation of erythroid precursors by preventing apoptosis. Proc. Natl. Acad. Sci. USA. 92: 9623-9627

88. Briegel K, Bartunek P, Stengl G, Lim K-C, Beug H, Engel D and Zenke M (1996) Regulation and function of transcription factor GATA-1 during red blood cell differentiation. Development 122: 3839-3850

89. Crossley M and Orkin SH (1994) Phosphorylation of the erythroid transcription factor GATA-1. J. Biol. Chem. 269: 16589-16596

90. Blobel GA and Orkin SH (1996) Estrogen-induced apoptosis by inhibition of the erythroid transcription factor GATA-1. Mol. Cell. Biol. 16: 1687-1694

91. Shimamoto T, Nakamura S, Bollekens J, Ruddle FH and Takeshita K (1997) Inhibition of $D L X-7$ homeobox gene causes decreased expression of GATA-1 and c-myc genes and apoptosis. Proc. Natl. Acad. Sci. USA 94: 3245-3249
92. Hagemeier C, Bannister AJ, Cook A and Kouzarides T (1993) The activation domain of transcription factor PU. 1 binds the retinoblastoma (RB) protein and the transcription factor TFIID in vitro: RB shows sequence similarity to TFIID and TFIIB. Proc. Natl. Acad. Sci. USA 90: 1580-1584

93. Nagulapalli S, Pongubala JM and Atchison ML (1995) Multiple proteins interact with PU.1. Transcriptional synergy with NF-IL6 $\beta$ (C/EBP $\delta$, CRP3). J. Immunol. 155: $4330-4338$

94. Hallier M, Tavitian A, Moreau-Gachelin F (1996) The transcription factor Spi-1/ PU. 1 binds RNA and interferes with the RNA-binding protein $\mathrm{p} 54^{\mathrm{nrb}}$. J. Biol. Chem. 271: $11177-11181$

95. Hallier M, Lerga A, Barnache S, Tavitian A and Moreau-Gachelin F (1998) The transcription factor Spi-1/PU.1 interracts with the potential splicing factor TLS. J. Biol. Chem. 273: 4838-4842

96. Janknecht R and Hunter T (1996) Transcription. A growing coactivator cascade. Nature 383: 22-23

97. Giles RH, Retters DJM and Breuning MH (1998) Conjunction dysfunction: CBP/ p300 in human diseases. Trends Genet. 14: 178-183

98. Chrivia JC, Kwok RPS, Lamb N, Hagiwara M, Montominy MRand Goodman RH (1993) Phosphorylated CREB binds specifically to the nuclear protein CBP. Nature 365: 855-859

99. Yang C, Shapiro LH, Rivera M, Kumar A and Brindle PK (1998) A role for CREB binding protein and p300 transcriptional coactivator in Ets-1 transactivation functions. Mol. Cell. Biol. 18: 2218-2229

100. Ogryzko VV, Schitz RL, Russanova V, Howard BH and Nakatani Y (1996) The transcriptional coactivators $\mathrm{p} 300$ and $\mathrm{CBP}$ are histone acetyltransferases. Cell 87: $953-959$

101. Shikama N, Lyon J and La Thangue NB (1997) The p300/CBP family: integrating signals with transcription factors and chromatin. Trends Cell Biol. 7: $230-236$

102. Gu W and Roeder RG (1997) Activation of $p 53$ sequence-specific DNA binding by acethylation of p53 C-terminal domain. Cell 90: 595-606

103. Boyes J, Byfield P, Nakatani Y and Ogryzko V (1998) Regulation of activity of the transcription factor GATA-1 by acethylation. Nature 396: $594-598$

104. Eckner R, Yao TP, Oldread E and Livingston DM (1996) Interaction and functional collaboration of p300/CBP and bHLH proteins in muscle and B-cell differentiation. Genes Dev. 10:2478-2490

105. Tanaka Y, Naruse I, Maekwa T, Masuya H, Shiroishi T and Ishii S (1997) Abnormal skeletal patterning in embryos lacking a single Cbp allele: A partial similarity with Rubinstein-Taybi syndrome. Proc. Natl. Acad. Sci. USA 94 10215-10220

106. KameiY, XuL, HeinzelT, Torchia J, Kurokawa R, Gloss B, Lin S-C, Heyman RA Rose DW, Glass CK and Rosenfeld MG (1996) A CBP integrator complex mediates transcriptional activation and $\mathrm{AP}-1$ inhibition by nuclear receptors Cell 85: 403-414

107. Weiss MJ and Orkin SH (1995b) GATA transcription factors: Key regulators of hematopoiesis. Exp. Hematol. 23: 99-107

108. Seth A, Robinson L, Thompson DM, Watson DK and Papas TS (1993) Transactivation of GATA-1 promoter with ETS1, ETS2 and ERGB/Hu-FLI-1 protein: stabilization of the ETS1 protein binding on GATA-1 promoter sequences by monoclonal antibody. Oncogene 8: 1783-1790

109. Stunnenberg HG, Garcia-Jimenez C and Betz JL (1998) Leukemia: the sophisticated subversion of hematopoiesis by nuclear receptor oncogene. Biochim. Biophys. Acta 1423: F15-F33

110. Olson MF, Paterson HF and Marshall CJ (1998) Signal from Ras and Rho GTPases interact to regulate expression of $21^{\text {waf1/Cip1 }}$. Nature 394:295-299

111. Sewing A, Weisman B, Lloid AC and Land H (1997) High-intensity Raf signa causes cell cycle arrest mediated by p21 ${ }^{\mathrm{Cip} 1}$. Mol. Cell. Biol. 17: 5588-5597

112. Lin AW, Barradas M, Stone JC, van Aelst L, Serrano M and Lowe SW (1998) Premature senescence involving $\mathrm{p} 53$ and $\mathrm{p} 16$ is activated in response to constitutive MEK/MAPK mitogenic signaling. Genes Dev. 12: 3008-3019

113. Zhu J, Wood D, McMartin M and Bishop JM (1998) Senescence of human fibroblasts induced by oncogenic Raf. Genes Dev. 12: 2997-3007

114. Mowat MRA (1998) p53 in tumor progression: life, death, and everything. Adv. Cancer Res. 65: 25-48

115. Munroe DG, Peacock J and Bechimol S (1990) Inactivation of the cellular p53 gene is a common feature of Friend erythroleukemia: relation to dominant transforming alleles. Mol. Cell Biol. 10: 3307-3313

116. Ryan JJ, Danish R, Gottlieb CA and Clarke MF (1993) Cell cycle analysis of p53 induced cell death in murine erythroleukemia cells. Mol. Cell. Biol. 13:711-719 
117. Ben-David Y, Giddens EB, Letwin K and Bernstein A (1991) Erythroleukemia induction by Friend murine leukemia virus: insertional activation of a new member of the ets gene family, Fli-1, closely linked to c-ets-1. Genes Dev. 5: $908-918$

118. Starck J, Doubeikovski A, Sarrazin S, Connet C, Rao G, Skoultchi A, Godet J Dusanter-Fourt I and Morle F (1999) Spi-1/PU.1 is a positive regulator of the Fli1 gene involved in inhibition of erythroid differentiation in Friend erythroleukemic cell lines. Mol. Cell. Biol. 19: 121-135

119. May WA, Lessnick SL, Braun BS, Klemsz M, Lewis BC, Lunsford LB, Hromas $R$ and Denny CT (1993) The Ewing's sarcoma EWS/Fli-1 fusion gene encodes a more potent transcriptional activator and is a more powerful transforming gene than Fli-1. Mol. Cell. Biol. 13: 7393-7398

120. Yi H, Fujimura Y, Ouchida M, Prasad DDK, Rao VN and Reddy ESP (1997) Inhibition of apoptosis by normal and aberrant Fli-1 and erg proteins involved in human solid tumors and leukemias. Oncogene 14: 1259-1268

121. Athanasiou M, Clausen PA, Mavrothalassitis GJ, Zhang X-K, Watson DK and Blair DG (1996) Increased expression of the ETS-related transcription factor FLI-1/ERGB correlates with and can induce the megakaryocytic phenotype. Cell Growth Differ. 7: 1525-1534

122. Huang C-C, Papas TS and Bhat NK (1997) A variant form of ETS1 induces apoptosis in human colon cancer cells. Oncogene 15: 851-856

123. Yamasaki L, Jacks T, Bronson R, Goillot E, Haelow E and Dyson NJ (1998) Tumor induction and tissue atropy in mice lacking E2F-1. Cell 88: 537-548

124. Noda M, Ko M, Ogura A, Lin D, Amano T, Takano T and Ikawa Y (1985) Sarcoma viruses carrying ras oncogenes induce differentiation-associated properties in a neuronal cell line. Nature 318: 73-75

125. Rivera RR, Stuiver MH, Steenberg R and Murre C (1993) Ets protein: New factors that regulate immunoglobulin-heavy chain gene expression. Mol. Cell. Biol. 13: 7163-7169

126. Pongubala JMR, Beveren CV, Nagulapalli S, Klemsz MJ, McKercher SR, Mak RA and Atchison ML (1993) Effect of PU.1 phosphorylation on interaction with NF-EM5 and transcriptional activation. Science 259: 1622-1625

127. Shin MK and Koshland ME (1993) Ets related protein PU.1 regulates expression of the immunoglobulin J-chain gene through novel Ets-binding element. Genes Dev. 7: 2006-2015

128. Omori SA and Wall $R$ (1993) Multiple motifs regulate the B-cell-specific promoter. Proc. Natl. Acad. Sci. USA 90: 11723-11727

129. Hagman $\mathrm{J}$ and Grosschedl R (1992) An inhibitory carboxyl-terminal domain in Ets-1 and Ets-2 mediates differential binding of Ets family factors to promoter sequences of the $m b-1$ gene. Proc. Natl. Acad. Sci. USA 89: 8889-8893

130. Ying H, Chang J-F, Parnes JR (1998) PU.1/Spi-1 is essential for the B cellspecific activity of the mouse CD72 promoter. J. Immunol. 160: 2287-2296

131. Himmelmann A, Thevenin C, Harrison K and Kehrl JH (1996) Analysis of Burton's tyrosine kinase gene promoter reveals critical PU.1 and Sp1 sites. Blood 87: 1036-1044

132. Borrás FE, Lloberas J, Maki RA, Celada A (1995) Repression of I-A $\beta$ gene expression by the transcription factor PU.1. J. Biol. Chem. 270: 2438524391

133. Imamura F, Takai S, AkagiK, Ando M, Yamamura K, Takatsu Kand Tominaga A (1994) The murine interleukin-5 receptor $\alpha$-subunit gene: characterization of the gene structure and chromosome mapping. DNA Cell Biol. 13: 283-292

134. Zhang D-E, Hetherington CJ, Chen H-M and Tenen DG (1994) The macrophage transcription factor PU.1 directs tissue-specific expression of the macrophage colony-stimulating factor receptor. Mol. Cell. Biol. 14: $373-$ 381

135. Smith LT, Hohaus S, Gonzalez DA, Dziennis SE and Tenen DG (1996) PU.1 (Spi-1) and $\mathrm{C} / \mathrm{EBP} \alpha$ regulate the granulocyte colony-stimulating factor receptor promoter in myeloid cells. Blood 88: $1234-1247$

136. Hohaus S, Petrovick MS, Voso MT, Sun Z, Zhang D-E and Tenen DG (1995) PU.1 (Spi-1) and C/EBP $\alpha$ regulate expression of the granulocyte-macrophage colony stimulating factor receptor $\alpha$ gene. Mol. Cell. Biol. 15: 5830-5845

137. Moulton KS, Semple K, Wu H and Glass CK (1994) Cell-specific expression of the macrophage scavenger receptor gene is dependent on PU.1 and a composite AP-1/ets motif. Mol. Cell. Biol. 14: 4408-4418

138. Pahl HL, Scheiber RJ, Zhang D-E, Chen H-M, Galson DL, Maki RA and Tenen DG (1993) The proto-oncogene PU.1 regulates expression of the myeloidspecific CD11b promoter. J. Biol. Chem. 268: 5014-5020

139. López-Cabrera M, Nueda A, Vara A, Garcia-Aguilar J, Togores A and Corbi AL (1993) Characterization of the $p 150,95$ leukocyte integrin a subunit (CD11c) gene promoter. J. Biol. Chem. 268: 1187-1193
140. Rosmarin AG, Caprio D, Levy R and Simkevich (1995) CD18 ( $\beta 2$ leukocyte integrin) promoter requires PU.1 transcription factor for myeloid activity. Proc. Natl. Acad. Sci. USA 92: 801-805

141. Perez C, Coeffier E, Moreau-Gachelin F, Wietzerbin J and Benech PD (1994) Involvement of transcription factor PU.1/Spi-1 in myeloid cell-restricted expression of an interferon-inducible gene encoding the human high-affinity Fcg receptor. Mol. Cell. Biol. 14: 5023-5031

142. Feinman R, Qui WQ, Pearse RN, Nikolajczyk BS, Sen R, Sheffery M and Ravetch JV (1994) PU.1 and an HLH family member contribute to the myeloidspecific transcription of the Fc $\gamma$ RIIIA promoter. EMBO J. 13: 3852-3860

143. Eichbaum Q, Heney D, Raveh D, Chung M, Davidson M, Epstein J and Ezekowitz AB (1997) Murine macrophage mannose receptor promoter is regulated by the transcription factor PU.1 and Sp1. Blood 90: 4135-4143

144. Ahne B and Strätling WH (1994) Characterization of a myeloid-specific enhancer of the chicken lysozyme gene. J. Biol. Chem. 269: 17794-17801

145. Kominato Y, Galson DL, Waterman WR, Webb AC and Auron PE (1995) Monocyte expression of the human prointerleukin $1 \beta$ gene $(I L 1 B)$ is dependent on promoter sequences which bind the hematopoietic transcription factor Spi-1/ PU.1. Mol. Cell. Biol. 15: 58-68

146. Ford AM, Bennet CA, Healy LE, Towatari M, Greaves MF and Enver T (1996) Regulation of myeloperoxidase enhancer binding proteins PU.1, C-EBP $\alpha,-\beta$ and $-\delta$ during granulocyte-lineage specification. Proc. Natl. Acad. Sci. USA 93: $10838-10843$

147. Ray-Gallet D, Mao C, Tavitian A and Moreau-Gachelin F (1995) DNA binding specificities of Spi-1/PU.1 and Spi-B transcription factors and identification of a Spi-1/Spi-B binding site in the c-fes/c-fps promoter. Oncogene 11: 303-313

148. Bodger MP and Hart DN (1998) Molecular cloning and functional analysis of the CD33 promoter. Br. J. Haematol. 102: 986-995

149. Sturrock A, Franklin KF and Hoidal JR (1996) Human proteinase-3 expression is regulated by PU. 1 in conjunction with a cytidine-rich element. J. Biol. Chem. 271: $32392-32402$

150. Nuchprayoon I, Simkevich CP, Lou M, Friedman AD and Rosemarin AG (1997) GABP cooperates with c-Myb and C/EBP to activate the neutrophil elastase promoter. Blood 89: 4546-4554

151. Suzuki S, Kumatori A, Haagen I-A, Fujii Y, Sada MA, Jun H, Tsuji Y, Roos D and Nakamura M (1998) PU.1 as an essential activator for the expression of gp $91^{\text {phox }}$ gene in human peripheral neutrophils, monocytes, and $B$ lymphocytes. Proc. Natl. Acad. Sci. USA 95: 6085-6090

152. LiS-L, Valente AJ, Zhao S-J and Clark RA (1997) PU. 1 is essential for p47phox promoter activity in myeloid cells. J. Biol. Chem. 272: 17802-17809

153. Wilkinson NC and Navarro J (1999) PU.1 regulates the CXCR1 promoter. J. Biol. Chem. 274: 438-443

154. van Dijk TB, Caldenhoven E, Raaijmakers JAM, Lammers J-W, Koenderman L and de Groot RP (1998) The role of transcription factorPU.1 in the activity of the intronic enhancer of the eosinophil-derived neurotoxin (RNS2) gene. Blood 91 : 2126-2132

155. Henkel G and Brown MA (1994) PU.1 and GATA: Components of a mast cellspecific interleukin 4 intronic enhancer. Proc. Natl. Acad. Sci. USA 91: 7734 7741

156. Bockamp E-O, Fordham JL, Göttgens B, Murrel AM, Sanchez M-J and Green AR (1998) Transcriptional regulation of the stem cell leukemia gene by PU.1 and Elf-1. J. Biol. Chem. 273: 29032-29042

157. Doubeikovski A, Uzan G, Doubeikovski Z, Pradini M-H, Porteu F, Gisselbrecht $S$ and Dusanter-Fourt I (1997) Thrombopoietin induced expression of the glycoprotein lib gene involves the transcription factor PU.1/spi-1 in UT7-Mpl cells. J. Biol. Chem. 272: 24300-24307

158. Zhang C, Gadue P, Scott E, Atchison M and Poncz M (1997) Activation of the megakaryocyte-specific gene platelet basic protein (PBP) by the Ets family factor PU.1. J. Biol. Chem. 272: 26236-26246

159. O'Prey J, Ramsay S, Chamber I and Harrison PR (1993) Transcriptional upregulation of the mouse cytosolic glutathione peroxidase gene in erythroid cells is due to tissue-specific $3^{\prime}$ enhancer containing functionally important CACC/ GT motifs and binding sites for GATA and Ets transcription factors. Mol. Cell. Biol. 13: 6290-6303

160. Laux G, Adam B, Strobl L and Moreau-Gachelin F (1994) The Spi-1/PU.1 and Spi-B ets family transcription factors and the recombination signal binding protein PBP-J $K$ interact with an Epstein-Barrvirus nuclear antigen 2 responsive cis-element. EMBO J. 13: 5624-5632

161. Carvalho M and Derse D (1993) The PU.1/Spi-1 proto-oncogene is transcriptional regulator of a lentivirus promoter. J. Virol. 67: 3885-3890 